\title{
Rancangan Aplikasi Bergerak Penjadwalan Distribusi Sembako pada UD. Kuning Mas Palangka Raya
}

Viktor Handrianus Pranatawijaya ${ }^{\mathrm{a}, 1, *}$

${ }^{a}$ Universitas Palangka Raya, Kampus Tunjung Nyaho Jalan Yos Sudarso, Palangka Raya, Kalimantan Tengah, Indonesia

${ }^{1}$ viktorhp@it.upr.ac.id*

\section{ARTICLE INFO}

\section{Keywords}

basic food

scheduling

distribution

mobile application

\section{ABSTRACT}

The role of suppliers and customers greatly affect the distribution of basic food that will be realized in distribution scheduling. In addition to suppliers and customers, several factors used in the preparation of scheduling are the location of suppliers and customers, time / period, and the route of the trip that is formed along with the status of the food delivered.

The initial step in making an application is needed is to make an analysis and design first. So the model used in this study is a modified Waterfall model. In the analysis section an application needs search is performed to determine the properties of the application to be made, such as management of user access rights and existing facilities and business process modeling using Unfied Modeling Language (UML), namely use case diagrams, activity diagrams, and class diagram. At the design stage it is used to create software blueprints. The things done include database design and application interface.

Existing facilities in this application that must be available are login and registration facilities, managing supplier and customer data as well as couriers, ordering groceries, and scheduling the distribution of groceries, as well as the status of food distribution. For further development of this research can implement the design of applications that are made. Moreover, it can determine the method of finding the route with the shortest distance or the route with the fastest time.

\section{Pendahuluan}

Sembilan Bahan Pokok atau sering disingkat Sembako adalah sembilan jenis kebutuhan pokok masyarakat. Kesembilan bahan pokok tersebut menurut Kepmenperindag 115/1998 adalah: [4] beras, gula pasir, minyak goreng dan mentega, daging sapi dan ayam, telur ayam, susu, jagung, minyak tanah, dan garam beryodium. Usaha Dagang (UD) Kuning Mas Palangka Raya memiliki usaha yang bergerak di bidang sembako. Distribusi sembako ke toko-toko merupakan salah satu kegiatan yang dilakukan pada UD. Kuning Mas Palangka Raya.

Menurut Philip Kotler (2010), saluran distribusi adalah suatu perangkat organisasi yang tergantung yang tercakup dalam proses yang membuat produk atau jasa menjadi untuk digunakan atau dikonsumsi oleh konsumen atau pengguna bisnis [3]. Sehingga sebuah jalur atau rute yang telah ditentukan diperlukan agar sembako dapat tersedia pada pelanggan. Rute dapat menjadi interaksi langsung antara pemasok dan pelanggan dalam hal ini adalah toko-toko. Oleh sebab itu, peran dari pemasok dan pelanggan sangat mempengaruhi distribusi sembako yang nantinya diwujudkan dalam penjadwalan distribusi.

Selain pemasok dan pelanggan, beberapa faktor yang digunakan dalam penyusunan penjadwalan adalah lokasi pemasok dan pelanggan, waktu/periode, dan rute perjalanan yang terbentuk beserta status dari sembako yang diantar. Penyajian informasi mengenai penjadwalan tersebut ditampilkan dalam bentuk rute perjalanan pada peta dan tabel mengenai status sembako yang diantar sehingga dapat memudahkan kurir dalam melakukan distribusi sembako. Dengan berkembangnya Teknologi 
Informasi (TI) maka untuk mempermudah pembuatan penjadwalan distribusi sembako diperlukan pembuatan aplikasi.

Langkah awal dalam pembuatan aplikasi diperlukan adalah membuat analisis dan desainnya terlebih dahulu. Sehubungan dengan informasi yang akan disajikan pada aplikasi penjadwalan maka pembuatan peta online dapat digunakan, menurut Muki salah satu peta online adalah Google Maps dan telah digunakan lebih dari 71,5 miliar orang [7]. Sehingga terdapat tiga informasi umum yang dapat dimasukkan dalam peta digital [6], yaitu: (1) informasi geografis yang merupakan informasi mengenai posisi bentuk-bentuk dari fitur geografis yang spesifik, (2) informasi atribut yang merupakan informasi non grafis mengenai tiap-tiap fitur, dan (3) informasi tampilan yang menjabarkan informasi tampilan fitur pada layar.

Pemanfaatan layanan dari Google Maps Application Programming Interface (API) digunakan dalam menampilkan peta, mengelola lokasi pemasok dan pelanggan, menampilkan rute distribusi beserta status sembako yang diantar. Menurut Trahan keunggulan dari API ini adalah memungkinkan suatu aplikasi dengan aplikasi lainnya dapat saling berhubungan dan berinteraksi. Bahasa pemrograman yang digunakan oleh Google Maps yang terdiri dari HTML, Javascript, dan AJAX serta XML, memungkinkan untuk menampilkan peta Google Maps di website dan aplikasi mobile [9].

Pemberian status sembako yang diantar dapat juga memanfaatkan layanan dari Location Based Service (LBS). Hal tersebut dilakukan dikarenakan menurut K"upper, LBS adalah layanan TI untuk memberikan informasi yang telah dibuat, disusun, dipilih, atau disaring dengan mempertimbangkan lokasi saat ini pengguna atau orang lain atau perangkat mobile [5].

Penggunaan Global Positioning System (GPS) pada LBS pun dimungkinkan dilakukan karena perangkat mobile sekarang sudah memiliki layanan GPS. Hal tersebut juga menunjukkan bahwa LBS berisi sejumlah komponen termasuk informasi peta dan Geographic Information System (GIS), layanan penentuan lokasi, dan subkomponen aplikasi tertentu [2]. Berdasarkan layanan TI yang telah dijabarkan sebelumnya maka dalam pembuatan aplikasi penjadwalan distribusi sembako, pemanfaatan Google Maps API dan penerapan GIS, LBS, dan GPS diterapkan.

Oleh sebab itu, untuk memudahkan pembuatan penjadwalan distribusi sembako maka diperlukan pembuatan aplikasi penjadwalan distribusi sembako dan tahap awal yang dilakukan dalam pembuatan aplikasi tersebut dilakukan analisis dan desain. Sehingga hal tersebut menjadi tahap yang sangat penting untuk dilakukan agar dalam pembuatan aplikasi nantinya dapat dilakukan.

\section{Metodologi Penelitian}

Dalam penelitian ini, metode penelitian yang dilakukan meliputi tahapan-tahapan penelitian dan lokasi penelitian. Berikut ini merupakan penjelasannya.

\subsection{Tahap-tahapan Penelitian}

Pada tahap-tahap penelitian secara umum terbagi menjadi dua bagian, yaitu (i) studi pustaka dan observasi, (ii) model Waterfall [7] yang dilakukan (analisis dan desain). Model yang digunakan merupakan suatu hasil dari siklus hidup pengembangan perangkat lunak [1]. Berikut ini merupakan beberapa tahapan penelitiannya, yaitu:

\section{Studi Pustaka dan Observasi}

Metode ini melakukan studi pustaka terhadap buku dan jurnal ilmiah sebagai pendukung dalam penelitian tentang distribusi, penjadwalan, peta, SIG, Google Map API, LBS, dan GPS. Observasi dilakukan untuk mengambil data-data untuk titik lokasi pemasok dan pelanggan, data waktu/periode yang umum digunakan untuk mengantar sembako, dan berapa besar radius yang diperlukan untuk 
mengetahui sembako telah berada pada lokasi pemasok ataukah pelanggan yang nantinya akan dijadikan area untuk mengeluarkan dan mengelola informasi.

\section{Model Waterfall yang dilakukan}

Pada perkembangannya banyak bermunculan modifikasi-modifikasi dari model Waterfall. Sehingga model yang digunakan pada penelitian ini merupakan model Waterfall yang modifikasi. Tahapan yang dilakukan pada model ini adalah analisis dan desain sistem.

Pada bagian analisis dilakukan pencarian kebutuhan aplikasi untuk mengetahui sifat-sifat dari aplikasi yang akan dibuat, seperti manajemen hak akses pengguna beserta fasilitas-fasilitas yang ada dan pemodelan proses bisnis dengan menggunakan Unfied Modeling Language (UML) yaitu use case diagram, activity diagram, dan class diagram. UML adalah bahasa standar yang digunakan untuk menjelaskan dan menvisualisasikan artifak dari proses analisis dan desain berorientasi objek. UML memungkinkan developer melakukan pemodelan secara visual, yaitu penekanan pada penggambaran. Pemodelan visual membantu untuk menangkap struktur dan perilaku dari objek, mempermudah penggambaran interaksi antara elemen dalam sistem, dan mempertahankan konsistensi antara desain dan implementasi dalam program.

Pada tahap desain digunakan untuk membuat blueprint software. Hal-hal yang dilakukan antara lain adalah perancangan basis data dan antarmuka aplikasi.

Tahap-tahapan penelitian yang dibuat dapat dilihat pada gambar 1. Berikut ini merupakan gambar dari Tahap-tahapan penelitian.

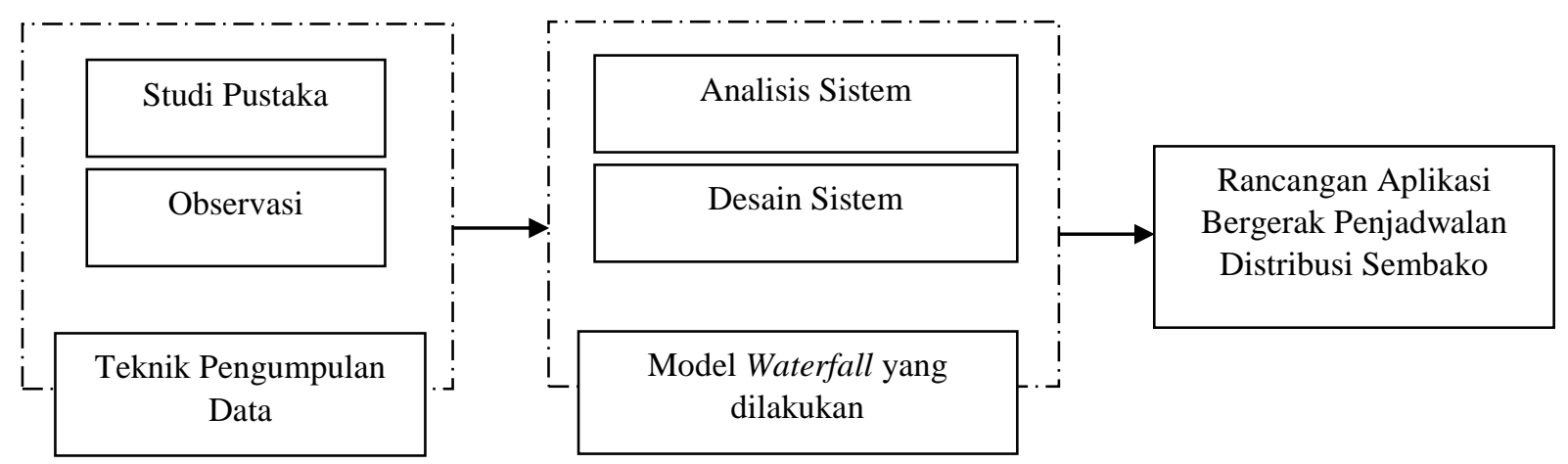

Gambar 1. Tahap-tahapan Penelitian

\subsection{Lokasi Penelitian}

Objek penelitian ini dilakukan pada kota Palangkaraya. Lokasi penelitian dikhususkan pada tokotoko dan UD. Kuning Mas Palangka Raya.

\section{Hasil dan Pembahasan}

Pada bagian hasil dan pembahasan merupakan uraian dan penjelasan dari tahap-tahapan penelitian yang ada pada gambar 1. Berikut ini merupakan penjelasannya. 


\subsection{Pengumpulan Data}

Pengumpulan data dilakukan pada tahap awal penelitian dengan dilakukannya studi pustaka dan observasi. Secara umum data utama yang ada adalah data pemasok, pelanggan, dan jadwal distribusi sembako. Atribut-atribut data untuk pemasok dan pelanggan pada umumnya sama yaitu, nama pemasok/pelanggan, alamat dan lokasi pemasok/pelanggan, serta nomor kontak yang dihubungi. Data yang lain adalah data kurir.

Pada jadwal distribusi sembako, atribut data yang ada adalah pemesanan sembako yang dilakukan, total perkiraan waktu yang diperlukan untuk mengantar sembako, status sembako, dan tanggal. Selain itu informasi yang ada adalah rute dari jadwal distribusi sembako pada peta.

\subsection{Hak Akses dan Fasilitas-fasilitas yang Ada}

Secara umum, pembuatan aplikasi bergerak penjadwalan distribusi sembako yang dibuat menggunakan Google Maps API, bahasa pemrograman Java pada Android Studio, dan basis data Firebase. Informasi yang akan diberikan berupa peta, teks, dan gambar. Pengguna dari aplikasi yang dibuat terbagi atas tiga hak akses yaitu (1) pemasok untuk melakukan pengelolaan informasi, (2) pelanggan untuk melihat dan mencari informasi serta memesan sembako, dan (3) kurir untuk mengupdate status sembako pada pemasok/pelanggan dan melihat jadwal distribusi sembako.

Proses bisnis yang ada pada aplikasi ini adalah langkah awalnya melakukan input data pemasok dan pelanggan. Setelah itu, dilakukan pemesanan sembako oleh pelanggan dan untuk waktu/periode penjadwalan distribusi sembako dilakukan dua sesi yaitu sesi pagi dan siang. Sembako nantinya akan diantarkan oleh kurir seuai dari waktu/periode pemesanan pelanggan. Pada saat pengantaran, kurir diberikan informasi mengenai rute perjalanan yang telah dijadwalkan berdasarkan pemesanan yang ada serta notifikasi bahwa kurir telah sampai ke tujuan. Setelah sembako telah diterima oleh pelanggan maka informasi pada jadwal distribusi sembako pun diperbaharui sehingga pemasok mengetahui informasi mengenai pelaksanaan jadwal distribusi sembako secara real time. Pada gambar 2 dapat penjelasan dari proses bisnis aplikasi ini.

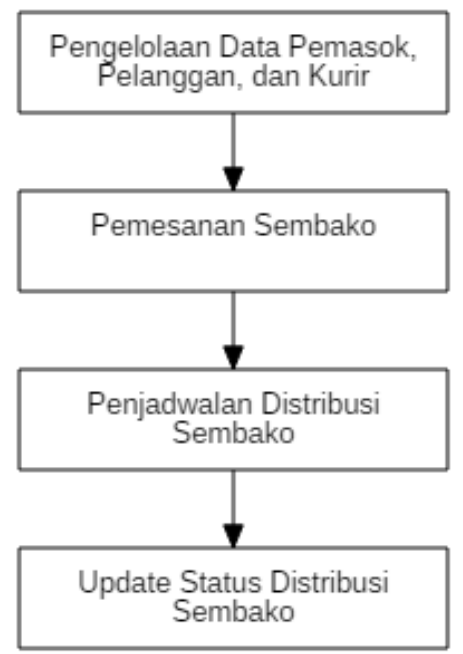

Gambar 2. Flowchart Diagram Penjadwalan Distribusi Sembako

Berdasarkan uraian di atas maka fasilitas-fasilitas yang ada pada aplikasi ini yang harus ada adalah fasilitas login dan registrasi, kelola data pemasok dan pelanggan serta kurir, pemesanan sembako, dan penjadwalan distribusi sembako, serta status distribusi sembako. 


\subsection{Use Case Diagram}

Use case diagram menggambarkan fungsionalitas yang diharapkan dari sebuah sistem. Sebuah use case merepresentasikan sebuah interaksi antara aktor dengan sistem. Adapun use case diagram untuk aplikasi bergerak penjadwalan distribusi sembako dapat dilihat pada gambar 3 berikut ini:

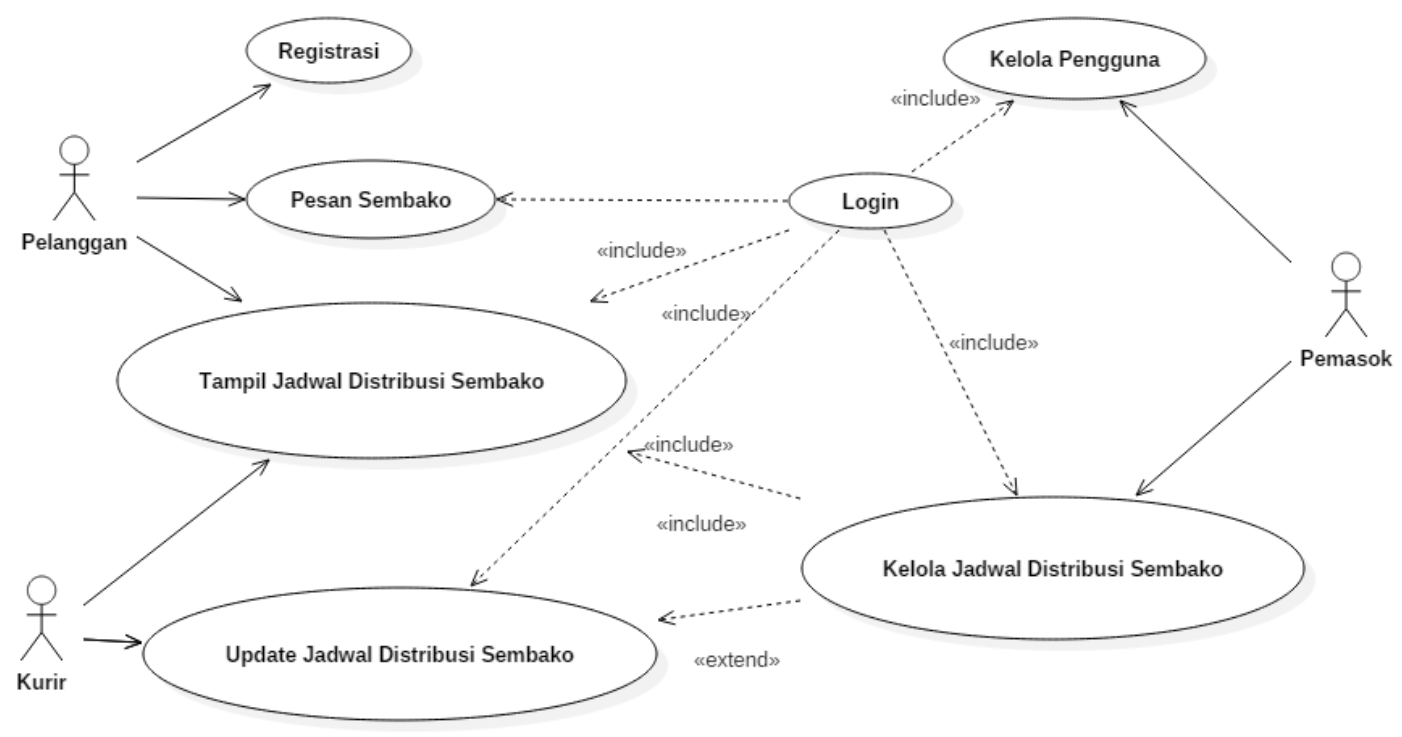

Gambar 3. Use Case Diagram Penjadwalan Distribusi Sembako

Berdasarkan gambar 3 di atas deskripsi pendefinisian aktor pada perancangan aplikasi dapat dilihat pada tabel 1 di bawah ini. Berikut ini merupakan penjelasannya.

Tabel 1.Tabel Definisi Aktor

\begin{tabular}{cll}
\hline \multirow{2}{*}{ No. } & \multicolumn{2}{c}{ Definisi Aktor } \\
\cline { 2 - 3 } 1 & Pemasok & \multicolumn{1}{c}{ Deskripsi } \\
\hline 2 & Pelanggan & $\begin{array}{l}\text { Pemasok mengelola semua layanan pada aplikasi yang } \\
\text { dibuat dan tugas utamanya adalah membuat penjadwalan } \\
\text { distribusi sembako }\end{array}$ \\
\hline 3 & Kurir & $\begin{array}{l}\text { Pelanggan dapat melakukan registrasi, pemesanan } \\
\text { sembako, dan dapat melihat jadwal distribusi sembako } \\
\text { yang dipesan }\end{array}$ \\
\hline
\end{tabular}

Selain melakukan mendeskripsikan defenisi aktor, dilakukan pula pendeskripsian use case. Berikut adalah deskripsi pendefinisian use case pada perancangan aplikasi dapat dilihat pada tabel 2 di bawah ini. Berikut ini merupakan penjelasannya. 
Tabel 2.Tabel Definisi Use Case

\begin{tabular}{|c|c|c|}
\hline \multirow{2}{*}{ No. } & \multicolumn{2}{|r|}{ Definisi Use Case } \\
\hline & Use Case & Deskripsi \\
\hline 1 & Login & $\begin{array}{l}\text { Login adalah use case yang digunakan untuk masuk ke } \\
\text { aplikasi untuk semua pengguna }\end{array}$ \\
\hline 2 & Registrasi & $\begin{array}{l}\text { Registrasi adalah use case yang digunakan pelanggan untuk } \\
\text { mendaftarkan dirinya sehingga dapat mengakses aplikasi }\end{array}$ \\
\hline 3 & Kelola Pengguna & $\begin{array}{l}\text { Mengelola pengguna adalah use case yang digunakan } \\
\text { untuk menambah,mengupdate,menampilkan,serta } \\
\text { menghapus data pengguna yang dilakukan oleh pemasok }\end{array}$ \\
\hline 4 & Pesan Sembako & $\begin{array}{l}\text { Pemesanan sembako adalah use case yang digunakan untuk } \\
\text { menambah data pemesanan oleh pelanggan }\end{array}$ \\
\hline 5 & $\begin{array}{l}\text { Kelola Jadwal Distribusi } \\
\text { Sembako }\end{array}$ & $\begin{array}{l}\text { Pengelolaan jadwal distribusi sembako adalah use case } \\
\text { yang digunakan untuk menambah, mengupdate, } \\
\text { menampilkan, serta menghapus jadwal distribusi sembako } \\
\text { yang dilakukan oleh pemasok }\end{array}$ \\
\hline 6 & $\begin{array}{l}\text { Tampil Jadwal Distribusi } \\
\text { Sembako }\end{array}$ & $\begin{array}{l}\text { Tampil jadwal distribusi sembako adalah use case yang } \\
\text { digunakan untuk menampilkan jadwal distribusi sembako } \\
\text { oleh semua pengguna }\end{array}$ \\
\hline 7 & $\begin{array}{l}\text { Update Status Distribusi } \\
\text { Sembako }\end{array}$ & $\begin{array}{l}\text { Update status distribusi sembako adalah use case yang } \\
\text { digunakan untuk memperbaharui status distribusi sembako } \\
\text { telah sampai ke pelanggan oleh kurir }\end{array}$ \\
\hline
\end{tabular}

\subsection{Activity Diagram}

Activity diagram menggambarkan berbagai aliran aktivitas dalam sistem yang sedang dirancang, dari awal aliran aktivitas, proses yang mungkin terjadi, dan bagaimana aktivitas tersebut berakhir. Activity Diagram untuk aplikasi bergerak penjadwalan distribusi sembako dapat dilihat pada gambar .

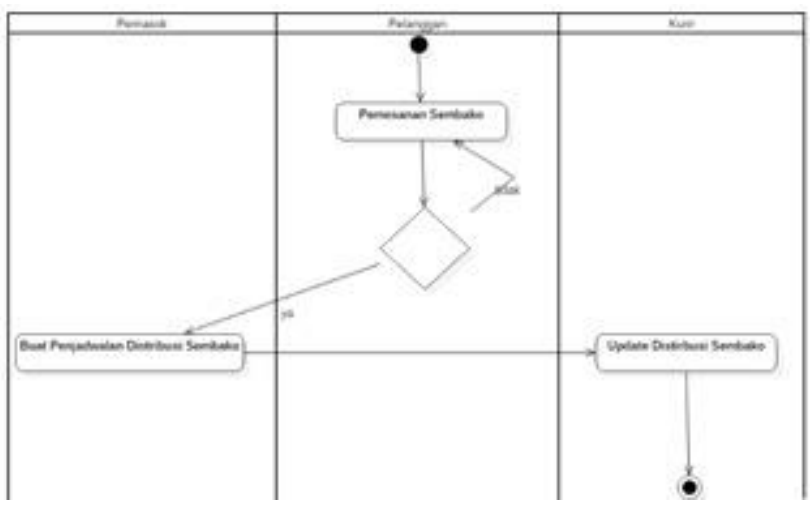

Gambar 4. Activity Diagram Penjadwalan Distribusi Sembako

Pada gambar 4, activity diagram yang dibuat merupakan aktifitas-aktifitas utama yang ada pada aplikasi saja. Penjelasan dengan menggambarkan sebagian dari keseluruhan aktifitas pada aplikasi ditujukan agar terlihat dengan jelas bahwa alur dari penjadwalan distribusi sembako dapat berjalan dengan baik jika aktifitas-aktifitas tersebut dilakukan.

\subsection{Class Diagram}

Class diagram merupakan suatu model untuk menjelaskan mengenai kelas, atribut, fungsi, dan keterhubungannya antar kelas. Class diagram digunakan pula untuk memodelkan struktur data dan hubungan antar data. Kelas yang terbentuk pada dasarnya bertujuan untuk mengatur pengguna, login, 
pemesanan, dan penjadwalan distribusi sembako. Untuk lebih jelasnya dapat dilihat pada gambar 5 berikut ini.

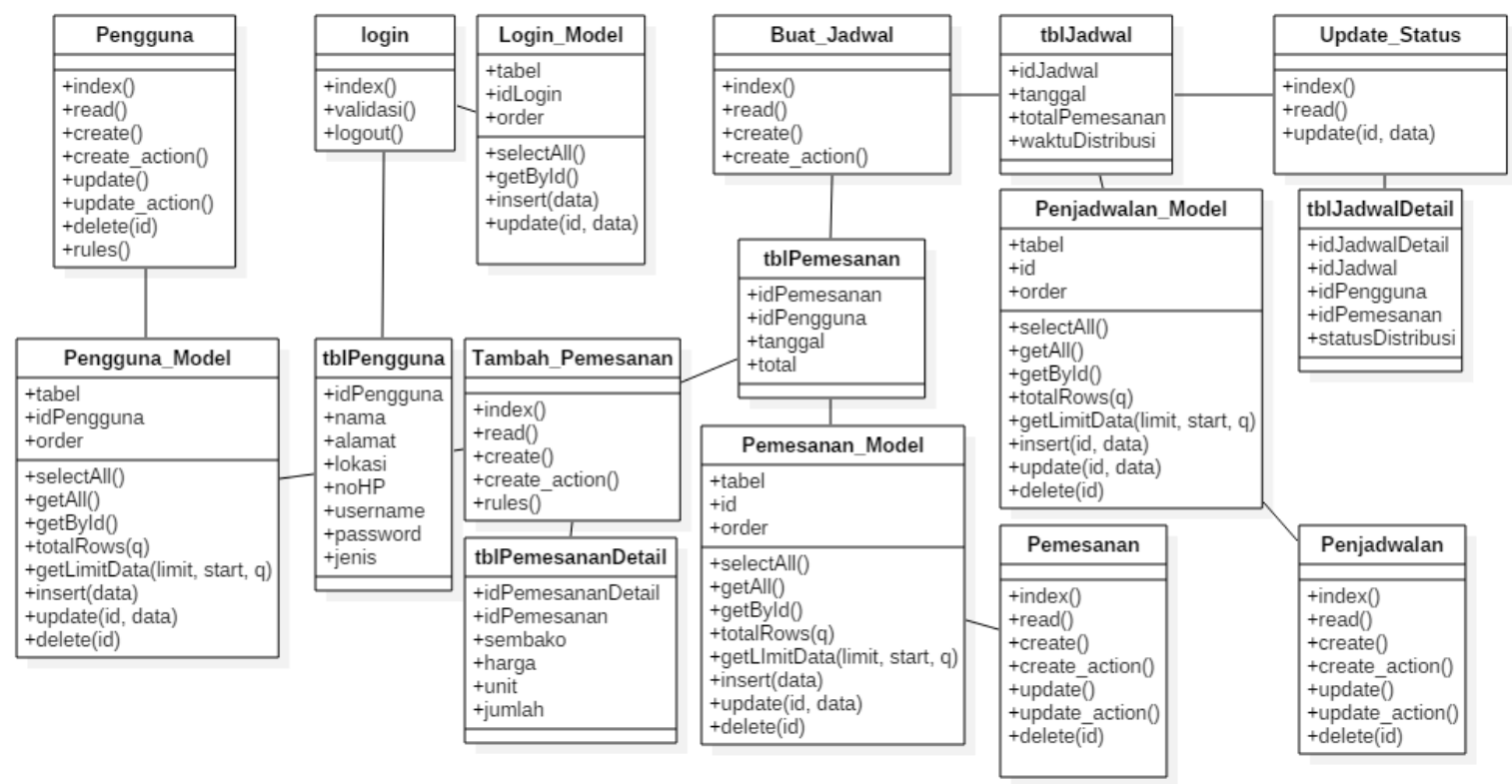

Gambar 5. Class Diagram Penjadwalan Distribusi Sembako

\subsection{Perancangan Basis Data}

Berdasarkan fungsionalitas dan class diagram terdapat penyimpanan dan pengambilan informasi berupa data-data pengguna, login, pemesanan, dan penjadwalan distribusi sembako. Data - data yang terdapat pada kelas-kelas dapat diklasifikasikan dalam bentuk tabel. Hubungan antar tabel pun dapat terlihat dari atribut-atribut data pada kelas.

Oleh sebab itu tabel yang terbentuk berjumlah lima yaitu tblPengguna, tblPemesanan, tblPemesananDetail, tblJadwalan, dan tblJadwalanDetail. Pada tblPengguna datanya adalah untuk menyimpan data pengguna dan digunakan pada fasilitas login agar dapat menggunakan aplikasi serta merupakan bagian dari data pemesanan dan penjadwalan. Field-field pada tblPengguna adalah idPengguna yang merupakan primary key, nama, alamat, lokasi, noHP, username, password, dan jenis yang digunakan untuk mengenali pengguna tersebut sebagai pemasok, pelanggan, atau kurir.

Pada tblPemesanan dan tblPemesananDetail, datanya untuk menyimpan pemesanan sembako yang dilakukan oleh pelanggan. Pada tblPemesanan field-fieldnya adalah idPemesanan sebagai primary key, idPengguna sebagai foreign key, tanggal, dan total harga pemesanan yang harus dibayarkan oleh pelanggan. Pada tblPemesananDetail field-fieldnya berisi data detail dari pemesanan yang dilakukan seperti idPemesananDetail sebagai primar key, idPemesan sebagai foreign key, sembako yang menandakan barang apa yg dipesan, harga, unit, dan jumlahnya.

Penjadwalan distribusi sembako data-datanya disimpan pada tabel tblJadwalan dan tblJadwalanDetail. Atribut/field pada tblPenjadwalan adalah idJadwal sebagai primar key, tanggal, totalPemesanan, dan waktuDistribusi. Sedangkan pada tabel tblJadwalanDetail field-fieldnya adalah idJadwalDetail sebagai primar key, idJadwal sebagai foreign key, idPengguna sebagai foreign key, idPemesanan sebagai foreign key, dan statusDistribusi. 


\subsection{Perancangan Antarmuka Aplikasi}

Pada bagian desain sistem dilakukan perancangan antarmuka dari sistem yang dibuat. Perancangan antarmuka yang dibahas adalah antarmuka yang memiliki peran dalam penjadwalan distribusi sembako. Rancangan antarmukanya adalah login beranda pemasok, pelanggan, dan kurir. Rancangan antar muka untuk pemesan dan penjadwalan distribusi sembako juga dijelaskan. Berikut ini uraiannya.

\subsubsection{Halaman Antarmuka Login}

Halaman antarmuka login memberikan fasilitas untuk dapat melakukan login, registrasi, lupa password, dan pengaturan agar selalu tetap masuk pada aplikasi. Inputan yang ada pada halaman ini adalah inputan username dan password.

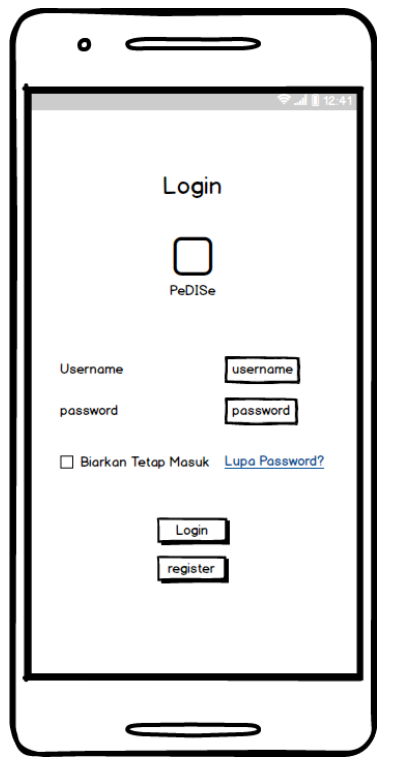

Gambar 6. Halaman Antarmuka Login

\subsubsection{Halaman Antarmuka Beranda Pemasok, Pelanggan, dan Kurir}

Rancangan halaman antarmuka beranda pemasok menampilkan informasi grafik mengenai jumlah pesanan dan status sembako yang didistribusi. Selain itu juga ditampilkan informasi pada table mengenai jadwal distribusi sembako. Pada bagian peta ditampilan rute dan lokasi kurir secara real time. Untuk rancangannya dapat dilihat pada gambar 7 urutan paling kiri.

Perbedaan rancangan halaman antarmuka pada beranda pelanggan adalah tidak adanya tampilan grafik dan di menu menjadi pengelolaan akun dan pemesanan sembako. Data yang tampil pada tabel di halaman antarmuka juga hanya ditampilkan data pelanggan yang sedang login. Gambar 7 posisi yang di tengah merupakan rancangan dari halaman antarmuka beranda pelanggan.

Pada rancangan halaman antarmuka beranda kurir, hamper sama dengan pada pelanggan, di menu terdapat pengelolaan akun. Pengelolaan status distribusi sembako pun diberikan pada menu halaman antarmuka beranda kurir. Rancangan halaman antarmuka beranda kurir ditampilkan pada gambar 7 dengan posisi paling kanan. 


\subsubsection{Halaman Antarmuka Pemesanan Sembako}

Rancangan halaman antarmuka pemesanan sembako dapat dilihat pada gambar 8. Informasi yang ada pada halaman tersebut adalah tanggal, sembako yang dipilih beserta jumlahnya. Pada bagian bawahnya digambarkan tabel yang memberikan informasi sembako-sembako yang dipesan. Tombol tambah dan pesan pun dibuat agar fasilitas dari halaman antarmuka pemesanan sembako dapat berjalan.

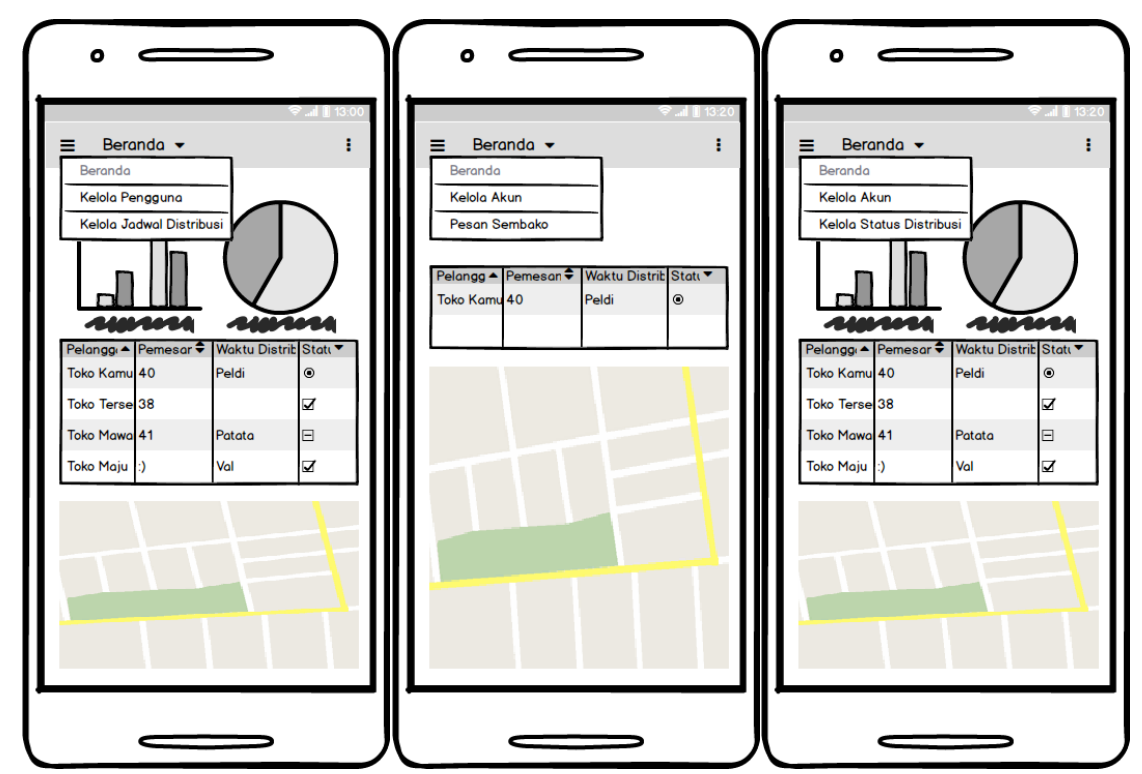

Gambar 7. Halaman Antarmuka Beranda Pemasok, Pelanggan, dan Kurir

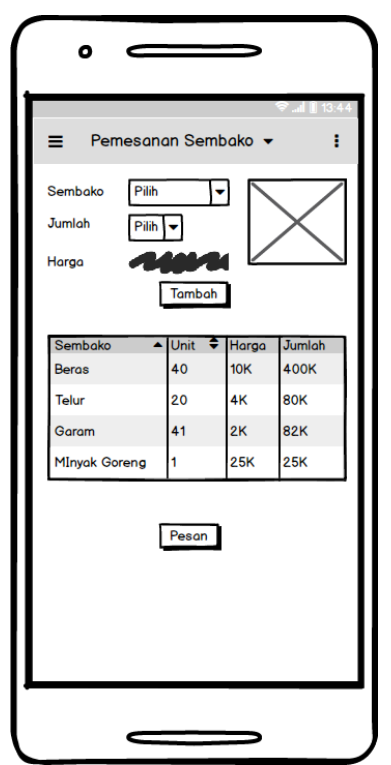

Gambar 8. Halaman Pemesanan Sembako

\subsubsection{Halaman Antarmuka Penjadwalan Distribusi Sembako}

Rancangan halaman antarmuka distribusi sembako menampilkan informasi dalam bentuk tabel mengenai jadwalnya dan rute perjalan pada peta yang ditampilkan. Tombol Buat jadwal distribusi 
digunakan untuk membuat jadwal distribusi secara otomatis dengan memperhatikan waktu/periode pemesanan dilakukan.

Gambar 9 menampilkan rancangan halaman antarmuka penjadwalan distribusi sembako. Setelah jadwal distribusi terbentuk maka akan ditampilkan dialog box yang memberitahukan bahwa status pembuatan jadwal berhasil.

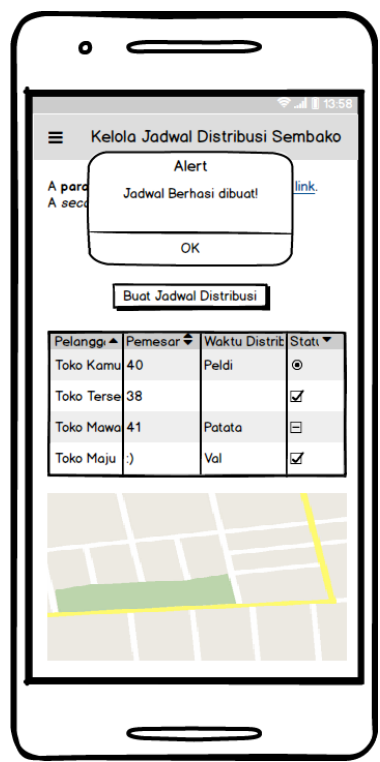

Gambar 9. Halaman Antarmuka Penjadwalan Distribusi Sembako

\section{Kesimpulan}

Kesimpulan yang dapat diambil setelah melalui proses perancangan aplikasi bergerak penjadwalan distribusi sembako pada UD. Kuning Mas Palangka Raya adalah bahwa perancangan aplikasi bergerak penjadwalan yang dibuat dengan menggunakan model waterfall dengan tahapan analisis dan desain. Pada bagian analisis dilkakukan pemetaan hak akses dan fasilitas-fasilitas yang ada serta penerapan UML. Tahapan desain dilakukan perancangan basis data dan halaman antarmuka aplikasi.

Faktor dan fasilitas yang diperlukan untuk penjadwalan distribusi sembako dapat berjalan dengan baik maka diperlukan pengguna yaitu pemasok, pelanggan, dan kurir yang pada aplikasi tersebut melakukan kegiatan seperti melakukan pemesanan sembako, pembuatan jadwal distribusi sembako, serta pengelolaan status distribusi. Pada proses registrasi juga sangat mempengaruhi karena pada saat itu lah pengguna yang nantinya menjadi pelanggan menginputkan lokasi tokonya di peta sehingga untuk penjadwalan distribus dan membuat rute perjalanan dapat dibuat jika ada pemesanan.

Untuk pengembangan lebih lanjut dari penelitian ini dapat mengimplementasikan rancangan aplikasi yang dibuat. Selain itu dapat menentukan metode pencarian rute dengan jarak terpendek atau rute dengan waktu tercepat. Penentuan prioritas distribusi juga dapat ditentukan menggunakan model seperti apa.

\section{Daftar Pustaka}

[1] Arcisphere technologies, Tutorial: The Software Development Life Cycle (SDLC), softwarelifecyclepros, 2012.

[2] Amit Kushwaha, Vineet Kushwaha, Location Based Services using Android Mobile Operating System International Journal of Advances in Engineering \& Technology, Mar 2011. IJAET ISSN: 2231-1963 14 Vol. 1,Issue 1,pp.14-20, 2011. 


\section{JURNAL TEKNOLOGI INFORMASI}

[E-ISSN 2656-0321]

[Vol 13. No. 2]

Jurnal Keilmunan dan Aplikasi Bitang Teknik Intormatika

[3] Kotler, Philip and Kevin Lane Keller, Manajemen Pemasaran, 13 ${ }^{\text {th }}$ ed, vol. 2, Erlangga, 2010.

[4] Kepmenperindag 115/1998, Jenis Barang Kebutuhan Pokok Masyarakat, Keputusan Menteri Perindustrian dan Perdagangan. Nomor: 115/MPP/Kep/2/1998, 27 Februari 1998.

[5] K“upper, Axel, Location-based Services. Fundamentals and Operation. John Wiley \& Sons Ltd, 2005.

[6] MindSites Group, GISDataDepot - GIS Data Formats. GIS Data Depot®, Geocomm, 2012.

[7] Muki Haklay et al, Web Mapping 2.0: The Neogeography of the GeoWeb. Geography Compass 2/6, 20112039, 10.1111/j.1749-8198.2008.00167.x. Journal Compilation, Blackwell Publishing Ltd , 2008.

[8] Royce, Winston. Managing the Development of Large Software Systems, Proceedings of IEEE WESCON 26 (August): 1-9, 1970.

[9] Trahan, S., Nguyen, M., Allred, I., Jayaram, Preethi. Integrating Geocode Data from the Google Map API and SAS/Graph, 2008. 